\title{
The Church Tower of Santiago Apóstol in Montilla: An Eco-Sustainable Rehabilitation Proposal
}

\author{
M. Araceli Calvo-Serrano ${ }^{1, *(\mathbb{D})}$, Isabel L. Castillejo-González ${ }^{1}{ }^{\mathbb{D}}$, Francisco Montes-Tubío ${ }^{1}$ and \\ Pilar Mercader-Moyano ${ }^{2, * \mathbb{D}}$ \\ 1 Department of Graphic Engineering and Geomatics, Campus de Rabanales, University of Cordoba, \\ 14071 Córdoba, Spain; ma2cagoi@uco.es (I.L.C.-G.); ir1motuf@uco.es (F.M.-T.) \\ 2 Department of Building Construction I, University of Seville, Reina Mercedes Avenue 2, 41012 Seville, Spain \\ * Correspondence: acalvoserrano@me.com (M.A.C.-S.); pmm@us.es (P.M.-M.); \\ Tel.: +34-660-503-494 (M.A.C.-S.); +34-618-305-559 (P.M.-M.)
}

Received: 29 July 2020; Accepted: 28 August 2020; Published: 31 August 2020

check for updates

\begin{abstract}
Is it possible to carry out eco-sustainable rehabilitations on specially protected buildings? This is the main question and starting point for this research. We will use the tower of the Church of "Santiago Apóstol" in Montilla as a case study; with its most remote antecedents in the 15th century, it is an emblematic building of one of the most important cities in the Cordovan countryside and is listed as an Asset of Cultural Interest (Bien de Interés Cultural or BIC) as of 2001. The application of eco-efficiency criteria in the rehabilitation of this type of building might stimulate the reactivation of the construction sector in the rural area, positively impacting the promotion of a circular economy. To this end, a general methodology has been established for carrying out eco-sustainable renovations on this type of building, which defines indicators for evaluating the eco-sustainability of such interventions. This methodology is applied to the case study of this important building in Montilla to ensure that a feasible intervention has been proposed, aligned with three basic pillars of sustainability that considers its environmental, economic, and social impact.
\end{abstract}

Keywords: patrimony; tower; buildings rehabilitation; eco-sustainable; sustainable; town planning; resource efficiency; eco-efficient construction solutions

\section{Introduction}

The restoration of historical buildings aims to preserve their architectural and artistic elements so that they faithfully illustrate their evolution through history, allowing the history of a building to be read through its architecture. Special attention must be paid when buildings are listed as Assets of Cultural Interest (BIC in Spanish) [1], regulated by the Spanish and Andalusian Historical Heritage laws $[2,3]$.

In order to preserve the beauty of this heritage, it is necessary to indicate the pertinent works of repair, conservation, reconstruction, and restoration. For the intervention in a building classified as Historical Heritage two processes must be carried out: A historical study and a safety evaluation. We wonder if it is possible to carry out a rehabilitation of this type of building while meeting eco-efficiency criteria. In the case of the Church Tower of Santiago Apóstol, multiple interventions have been carried out over the years. The last one was executed in 1989, and an additional conservation intervention would be necessary shortly after.

We think rehabilitation and eco-sustainable interventions on specially protected historical buildings can be key to reactivating the construction sector and general economy in rural areas. For decades, these regions have suffered from depopulation. As a result of the health and economic crisis in which we find ourselves today, a return of the population to these areas is highly plausible, with all that this 
may entail. The application of strategies and methods in the field of eco-sustainability, while respecting the environment and the impact on buildings, will also favor the flow of human, material, and financial resources in the area, generating employment and promoting tourism in the region and bolstering its economic development.

In the enhancement of these architecturally and historically relevant buildings, we understand that two essential aspects must be considered: Materials and eco-sustainability. The physical qualities of the materials used (texture, shine, surface, appearance, etc.) must be in line with the space, awakening the senses of its viewer, integrating the renovated portions with the history of the building and the environment $[4,5]$. The materials used will play a fundamental role in the eco-sustainability of the rehabilitation. Carrying out the intervention from an eco-sustainable point of view will reduce not only energy consumption, but also the impact on the environment and the generation of waste.

In the context of the current economic crisis, it is also necessary to search for strategies that contribute to reactivating the construction sector, while achieving the preservation and maintenance of these specially protected historical buildings.

The legal concept of sustainability arises from the United Nations Framework Convention on Climate Change [6], when society and governments begin to gain awareness of the danger of greenhouse gas emissions. After that, the Kyoto Protocol [7] continues along the same lines at the international level, and Directives 2010/31/EU, 2012/27/UE, and 2018/844/UE establish a series of minimum requirements and objectives at a European level for the energy efficiency of buildings [8], including a 20\% reduction in minimum consumption compared to 1990 levels by 2020. There is an exemption in this regard for religious and officially protected buildings. Also, the Spanish and Andalusian Historical Heritage Laws [2,3] establish a principle of minimum intervention in these buildings, requiring that the contributions of all existing historical periods be respected in the restorations.

It is becoming common to carry out a rehabilitation of these buildings while applying eco-sustainable criteria and taking into account the challenges and limitations that may present themselves in the process. Some of these problems include space, the conservation requirements for protected elements, and the economic investment that this requires, which in many cases is not easily assumed by the property holder.

This article aims to address and analyze the rehabilitation of the tower of the Church of Santiago Apóstol in Montilla from an eco-sustainable point of view, while giving the necessary importance to its context.

\section{Materials and Methods}

The eco-sustainable rehabilitation of specially protected buildings is a topic of great interest today. For this reason, in this article, we will establish a general method for such an undertaking, analyzing its applicability through specific study case, the tower of the Church of Santiago Apóstol in Montilla (Córdoba). We will also detail how to carry out a future intervention by applying eco-sustainable rehabilitation parameters, detecting the challenges that may arise, and how to solve them.

\subsection{Methods for Evaluating Rehabilitation with Eco-Sustainable Criteria}

The absence of a uniform method for evaluating the rehabilitation of a historic building with eco-sustainable criteria $[9,10]$ makes it possible to propose a model, which establishes key eco-sustainable evaluation performance indicators. Our main objective is to establish an eco-sustainable model for the rehabilitation of protected buildings like the tower of the Church of Santiago.

Using the methodology of the Integrative Model of Values for Sustainable Evaluations (MIVES) [11] as a starting point, we have determined some quality indicators that are representative, quantifiable, and precise for evaluating the rehabilitation of historical and protected buildings such as this tower; we have done so while considering the three pillars of eco-sustainability (environmental, social, and economic). This method has been developed by the Polytechnic University of Catalonia. It is a methodology of multicriteria decision-making that establishes value indicators for evaluating 
alternatives in order to solve problems in favor of sustainable rehabilitations. It establishes a series of phases, starting from the delimitation of the decision, and organizes the aspects to be considered in a branching manner in the form of a decision-making tree. It takes into account who takes the decision, what the limits are, and its conditions, including, for example, the requirements, components and life cycle of materials, among others. It then creates value functions and assigns a weight to each of the elements to then define possible alternatives to be considered when making decisions. Finally, these alternatives will be evaluated and analyzed to contrast the medium and long-term results in a control phase.

We think that starting from the MIVES methodology is convenient, given that one of its most important characteristics, as Viñolas explains, is that decisions are made prior to the intervention, defining both the aspects to be taken into consideration and how they are to be evaluated.

Though it is difficult to reduce the assessment of the sustainability of a rehabilitation to a series of indicators, establishing acceptance rates is the most objective way to do so. For this reason, some indicators have been identified in this regard and grouped as they relate to the three focuses of sustainability:

1. Environmental Focus:

- Energy consumed in the transport of material or components (ECTM) needed for the intervention. The fact that they must come from companies close to the place, as will be discussed below within the social focus, will have a positive impact on this indicator.

- Energy consumed in the installation and application process of the materials used (ECIP).

- Assessment of the degree of eco-sustainability of the material and natural resources used (ALEQ). In this case, measuring whether the resources used count as eco-sustainable or are in the process of obtaining an official quality certification in this regard.

- Level of use of reusable and recycled materials (LURRM), establishing a ratio between the total quantity of materials used and the portion that is reusable and recycled. A high rate of recycled and reusable materials will help indicate an eco-sustainable rehabilitation, and support the circular economy model, which in turn supports the reduction of raw materials through the application of the 3R concept (reduce, reuse, and recycle).

- Management of generated waste, measuring the level of waste generated and the treatment given. The aim is to minimize polluting waste in favor of biodegradable or reusable waste. We will make a distinction here between the level of reusable (MRW) and recycled waste (MRcW)

2. Social Focus:

- Ecological Footprint of Service and Resource Providers (EFSRP), as an indicator of the environmental impact of companies providing services and resources. Here, possessing an accreditation or being in the process of becoming accredited with some reputable certification will be considered [12].

- Distance from providers to the intervention site (DPIS). Reduced distance will bring benefits in terms of the impact on employment and generation of wealth in the local environment. It will also have positive consequences for the level of pollution generated by transportation.

- Hiring of labor from the local environment (LE). This will promote employment and generate wealth within the geographical environment where the intervention must be carried out. Especially when considering the economic crisis in which we find ourselves today as a consequence of the coronavirus pandemic, this can have direct positive effects.

3. Economic Focus: In the framework of a circular economy, it is not only necessary to reduce the cost for the company in its activities, but to reduce the entry of virgin materials and the production of waste. This criterion is directly related to the ecological footprint indicator previously explained, as well as the use of renewable energy. We must analyze the resulting logistics costs, which include the managing cost, storage cost, transport cost, administrative cost, and financial cost. 
Table 1 shows how to calculate each of these indicators and what their measurement units are, in addition to establishing acceptance rates for each of them. From ECTM and ECIP indicators, the acceptance rates should be established once suppliers have been selected, the distance at which they are located is known, and the electrical tools to be used have been determined.

Table 1. Calculation of the proposed quality indicators to eco-sustainable rehabilitation.

\begin{tabular}{|c|c|c|c|}
\hline INDICATOR & CALCULATION & UD & ACCEPTANCE INDEX \\
\hline ECTM & fuel consumption per $\mathrm{km}$ traveled $\times \mathrm{km}$ traveled & 1 & \\
\hline ECIP & Electric power of the tool used $(\mathrm{Kw}) \times$ Usage time $(\mathrm{h})$ & Kwh & \\
\hline$A L E Q$ & $\frac{\text { ecosustainable resources used }}{\text { total resources used }} \times 100$ & $\%$ & $90 \%$ \\
\hline LURRM & $\frac{\text { reusable and recycled materials used }}{\text { total resources used }} \times 100$ & $\%$ & $80 \%$ \\
\hline$M R W$ & $\frac{\text { total reusable waste }}{\text { total waste generated }} \times 100$ & $\%$ & $80 \%$ \\
\hline$M R c W$ & $\frac{\text { total non recycled waste }}{\text { total waste generated }} \times 100$ & $\%$ & $80 \%$ \\
\hline EFSRP & $\frac{\text { providers with quality certification }}{\text { total provider }} \times 100$ & $\%$ & $90 \%$ \\
\hline DPIS & distance between provider and the workplace $(\mathrm{km})$ & $\mathrm{km}$ & $20 \mathrm{~km}$ \\
\hline$L E$ & $\frac{\text { total local workers }}{\text { total hired workers }} \times 100$ & $\%$ & $80 \%$ \\
\hline
\end{tabular}

\section{Results}

\subsection{Descriptive and Historical Analysis}

To demonstrate the methodology outlined above, we will use the case study of the Santiago Apóstol Church of Montilla, a little town in Cordova, located in the center of Andalusia. For centuries it has been the most important church in the city, as part of the inherited cultural landscape that is integrated in the current urban reality. Various transformations have been carried out over the centuries, and it was declared an Asset of Cultural Interest in 2001.

Its exact origins are unknown. The first vestiges date from the 13th century [13-19]. In 1237, the territory was conquered under the command of King Ferdinand III, who in 1257 entrusted them to Gonzalo Yáñez, also known as Gonçalo Eanes Do Vinhal. The population settled and the medieval town was built around the hilltop castle and its fortress. It reached maximum splendor under Fernández de Córdoba and the lineage of the Casa de Aguilar [13], who resided there until 1508. Around it, as with most medieval towns, there were buildings and constructions of various kinds, among which the Church of Santiago stood out.

Within religious architecture, churches have great relevance. They satisfy the need of the people to have a space for prayer, which over time is transformed along with their environment. Since their origins, the conception of these buildings has followed some general guidelines. From the pre-Romanesque era, they began to be equipped with towers as a way of bringing humans closer to God. During the Middle Ages the alarifes (architects) increased their height. A weathervane with a cross or a rooster, which is a symbol of the Resurrection, was often placed on the roof of the towers.

The evolution reflected in the construction of the Church of Santiago is proof of the inseparable relationship between society and architecture. Although the building has undergone continuous transformations, its underlying structure has hardly been altered. According to Ramirez de Arellano, at the beginning of the 16th century, the Marques of Priego paid for some important work to be done on the building, which is now considered the first great reform, probably in response to the great demographic growth of the town, then the second most populated in the state of Priego [14]. Hernán Ruiz's reconstruction of the tower happened at this time.

Characteristics of the Mudejar style are observed, although some have disappeared with the passage of time, such as the coffered ceiling or the original main doorway [19]. This style prevails in the churches built in the current region of Cordova that come from the time of the Reconquest by Fernando III, as it is the case of the fernandine churches in Cordova city. 
We will focus our attention on two of the most important exterior elements that have survived until our times and about which very little information exists: the façade and the tower.

We must go back to the era of the Reconquest, where Christian temples were either built inside of old Muslim mosques, as was the case with the Church of San Lorenzo and the Cathedral of Cordova, or new churches were built to stand alone. The conversion of mosques into Christian churches has been addressed throughout history. García and Ortega [20] explore the topic of Christianized mosques in Toledo and Cordova, identifying three types of processes: Expansion, emptying, and general demolition. The objective of the conversion of the mosques into Christian churches during the Reconquest was to change the identity of the property, marking it for Christian worship. For this reason, the first action taken in this process was to add Christian furniture and liturgical elements before subsequently carrying out the architectural changes. The most frequent intervention was the transformation of minarets into church towers, as seen in the Cordovan churches of Santiago and San Lorenzo. The use of other architectural elements such as columns or ashlars and even walls was also frequent.

In Cordova there are very important fernandine churches, with a mix of Romanesque, Gothic, and Mudejar elements, with their signature wooden coffered ceilings and additional influence from the French Gothic and Cistercian styles [21].

Some studies $[14,16,17,22,23]$ establish that, after conquering the territory, the Church of Santiago was built upon an old mosque and consecrated to Christian worship, although no evidence has been found so far in the work carried out on the church or the surrounding area. Lorenzo Muñoz attributes the name of its main church to the day of the city's conquest on 25 July 1240 [15]. Antonio Jurado de Aguilar refers to the testament of Alonso Fernández de Córdoba, dated on 25 October 1235, in which he leaves ten thousand maravedis to the church to use for masses for his soul and for the construction of its main chapel. He also states that his grandson, Gonzalo Fernández de Córdoba, who was very devoted to the Apostle Santiago, contributed to the construction of a new altarpiece, presided over by a sculpture of Santiago [16]. There is not another written record on the church's architecture until the beginning of the 15th century. On 15 July 1437, a letter from the Bishop of Cordova dated 3 March 1422 , about the obligation to pay tithes to the church, is read and published [19].

Almost no records about the original façade of the church have been found. There are just a few brief references from the beginning of the 17th century, in which Lucas Jurado y Aguilar points out that the façade and main doorway were constructed in 1624 [17]. The façade appears in a drawing of the Montilla barn (alhorí) made by the Cordovan architect Juan Antonio Camacho, master builder of the Duke of Medinaceli and the Bishopric of Cordova [24]. In the upper right section of this drawing dated 1723, we can see the façade and the tower before its destruction by the 1755 earthquake (Figure 1). Typical details of a Renaissance doorway are present including the great attention paid to the harmony of proportions, following the guidelines established in Vitruvio's treatise De Architectura, a reference book for the architects of the time. The façades of this style consist of two main parts and a pediment, with classicist structural and decorative elements. Regarding the main bodies, the semicircular arch, columns, entablatures, and roof with coffered ceilings stand out, with values such as symmetry, simplicity, and structural clarity prevailing. As for the decorations, the pilasters, scrolls, keys, medallions, and the pediment are typical. Usually, a niche was included in the second section over the doorway with a sculpture of the saint to whom the church was dedicated [25]. We understand that it is not the original, since its style, as we have explained, is one that postdates the original construction of the church. Furthermore, documentation exists stating that it was rebuilt in 1624 [17]. If we compare this doorway with the alhorí built by Camacho we see how the architect was inspired by the doorway of the church (Figure 2). 


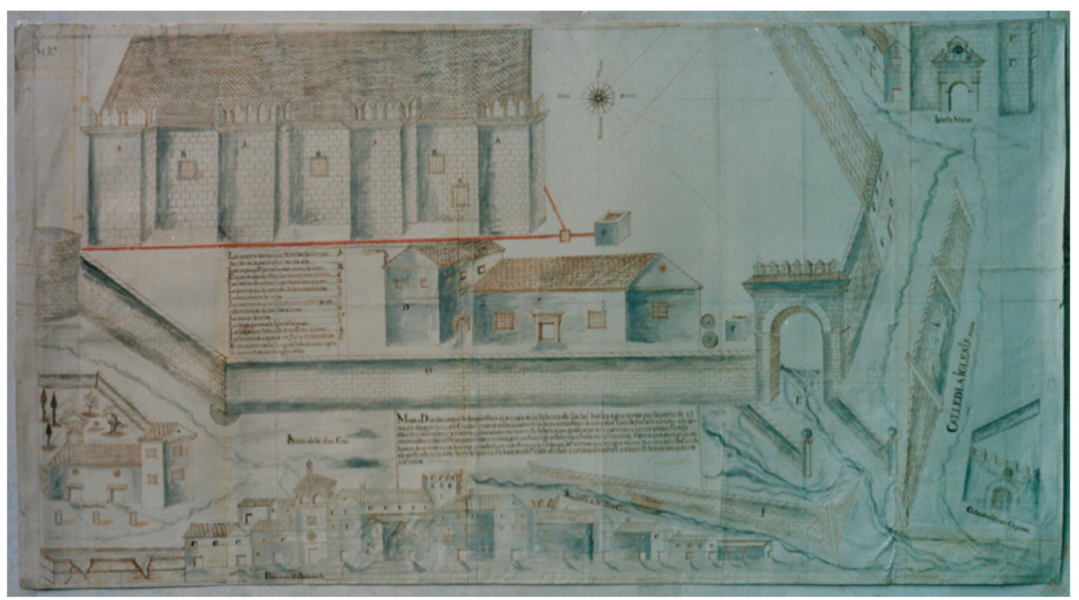

Figure 1. Plan for Montilla's barn built by Juan Antonio Camacho in 1723. (Archivo Ducal de Medinaceli, Sección Priego, Original. Leg 113, Num I).

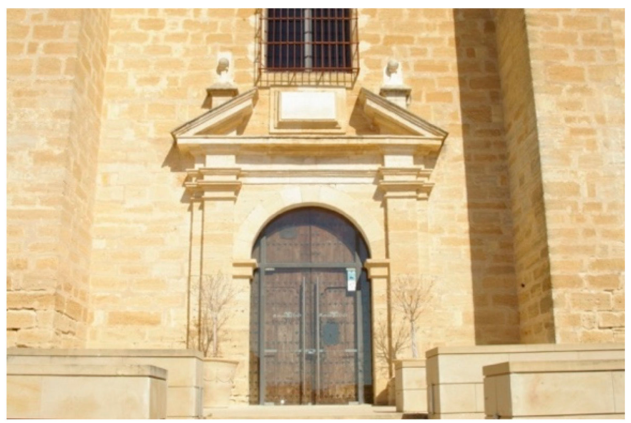

Figure 2. Facade of Montilla's barn built by Juan Antonio Camacho. (Author: A. Calvo).

To gain a clearer understanding of how the original façade of the church might have looked (Figure 3), and having consulted some documented references about its existence from as early as the 14th century, we must compare the façades of the fernandine churches in Cordova. They are simple, with buttresses and a rose window, and a main doorway at the foot of the central nave with pointed arches adorned with diamond tips ("punta de diamante") or dog teeth ("diente de perro") and crowned by a roof tile on modillions (Figure 4).

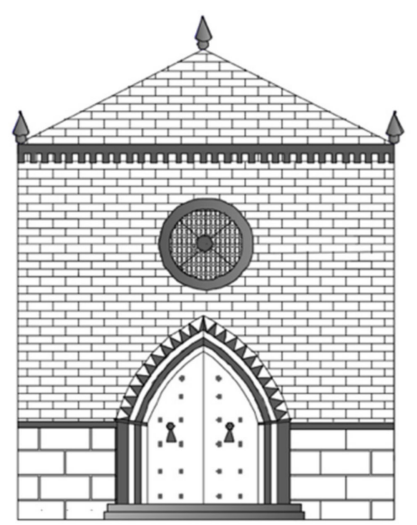

Figure 3. Outline of the possible doorway of the church of Santiago Apostol in Montilla in the 15th Century. (Author: A. Calvo). 


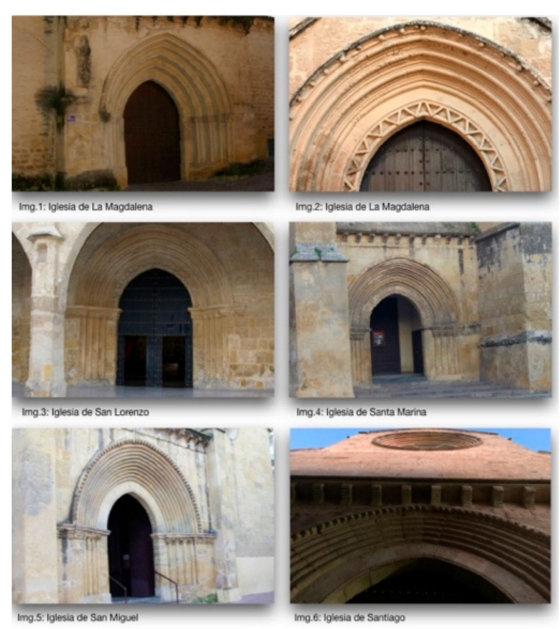

Figure 4. Details of the doorways of the most important fernandine churches in Cordova (Author: A. Calvo).

Taking Camachos's drawing (Figure 1) and the documentation consulted in various sources as a reference, it has been possible to approximate the main exterior of the church lost after the reform of the doorway in the early 17th century, when the tower designed by Hernán Ruiz was still standing (Figure 5). The imagined reconstruction of Hernan Ruiz's tower has been put together based on the description preserved in the Montilla Historical Archive [26] and drawings made by Enrique Garramiola, located in the Montilla Municipal Archive (Figure 6). The digital reconstruction of the 15th century doorway in (Figure 4) is based on a study of the fernandine churches of Cordova, built during this period.

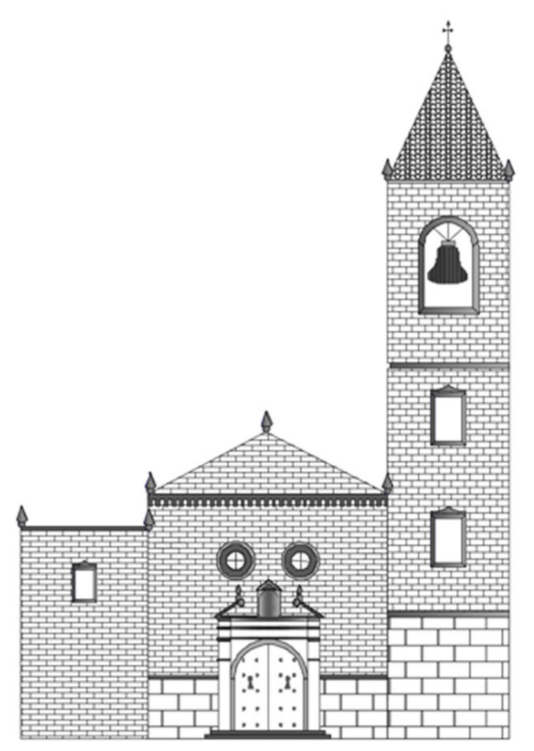

Figure 5. Elevation of the facade after the reconstruction of 1624 and the original tower of the Church of Santiago Apóstol of Montilla (Author: A. Calvo). 


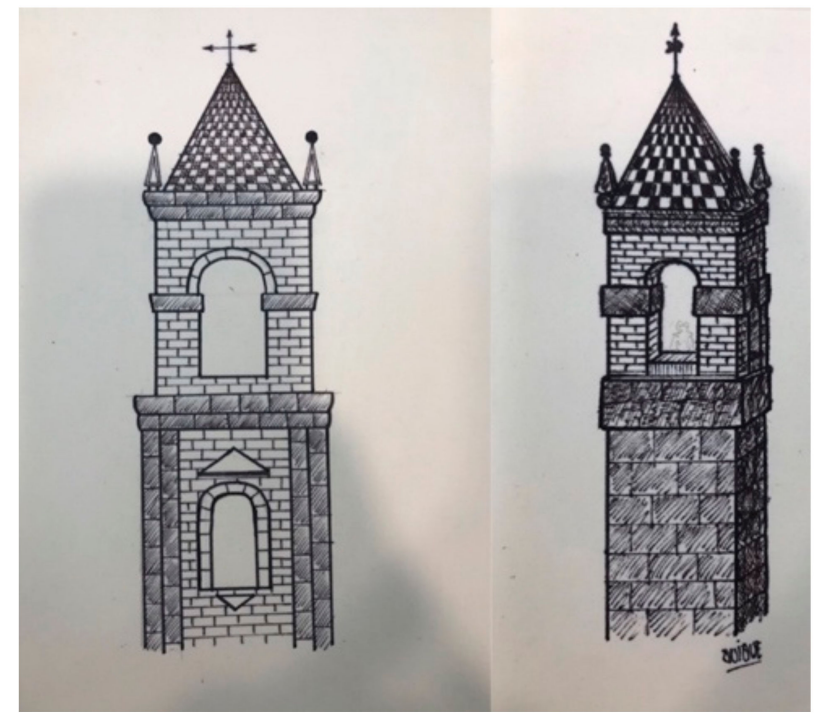

Figure 6. The tower of the Church of Santiago built by Hernán Ruiz, by Enrique Garramiola. (Municipal Archive of Montilla. Church of Santiago Folder).

On the outside, its tower-the main subject of this article—stands out prominently and can be seen from almost anywhere in the city.

It is well known that the current tower is not the original. Ramirez de Arellano said that, at the beginning of the 16th century, the Marquis of Priego paid for what can be understood as the first important reform [13]. This included a reconstruction of the tower by Hernán Ruiz, that crowned the church from the end of the 16th century to the 18th century. No documentation has been found about the architecture of the previous tower, although it is known that in between 1576 and 1577 Hernan Ruiz, senior teacher of the Bishopric of Cordova presented himself in Montilla for the rebuilding of this tower. According to the notes of Enrique Garramiola conserved in the Municipal Archive of Montilla, information on the status of the tower's construction and the church bells was collected in the Chapter Records on 21 April 1574. Some official writings on 30 March 1577 signed by the scribe Juan Martínez de Córdoba provide a wealth of information about it. This information includes the decision to demolish the primitive tower and use the demolition material for reconstruction, as well as to lower the bells of the tower and leave them in on the walkway of the church in the meantime [21]. They establish a period of three months from the 15th of April for the execution of the project and describe how the construction is to be executed, alluding to a drawing that accompanies the writing and that must have been lost at some point.

Garramiola refers to it in an article in which he describes how the tower should be built according to the contract they signed [18], alluding to a drawing by Hernán Ruiz that would serve as a guide for the construction project. The contract indicates that it should have a first stone section from the Aguilar quarry that is 20 feet long and a cornice. The second section would be of brick plastered with lime and sand and capitals of the same stone as the first section that framed the windows, with blue tiles embedded in the stone adorning the windows. There would be stone pyramids on the corners of the roof and a spiral staircase ascending to the bell of the tower.

Hernán Ruiz II explained in his architectural treatise how he organizes the construction of this tower, widespread throughout Andalusia. The absence of drawn plans of the Santiago tower leads us to think that it was similar to what Hernán Ruiz explains in the last pages of his manuscript, when he talks about the square floorplan and the development of the staircase of the church tower of San Lorenzo in Cordova, also his work. In the contract for the construction of the Santiago tower [26], the existence of a spiral staircase that goes up to the last section is mentioned. We can extrapolate that it was built in a way that is very similar to the way described by Hernán Ruiz in his treatise. Here, as 
Professor Navascués indicates [27], the sections are vaulted, sometimes with split voissoirs, others on half-barrel or sloping barrel vaults, or even with flat and sloping roofs. In addition, a comparison of the stairs of some other towers built by Hernan Ruiz and his son and grandson by the same name, such as the tower of the churches of Nuestra Señora de Soterraño (Aguilar de la Frontera), El Salvador (Pedroche), and San Mateo (Lucena), can help to clarify how the one in Santiago might have been. The one in Pedroche is very special, because it has a double handrail, which also functions as a drain.

With the help of these detailed descriptions, Garramiola draws a picture of the tower (Figure 6), which is kept in the Municipal Archive of Montilla. Both the written account and this drawing help to make an approximation of the tower, and lead to a comparison with towers of other churches from the time built by the Hernán Ruiz I-III in the kingdom of Cordova. Also, in the image of Montilla prepared by Pier Maria Baldi in 1668 for the book "Cosme de Medicis's journey though Spain and Italy", plate XXXVII shows a small sketch of this tower, which closely resembles those presented by Garramiola.

On November 1, 1755, one of the most virulent earthquakes remembered took place and would go down in history as the Lisbon earthquake. The devastating effects spread beyond Portugal. In Montilla, it was felt between 09:45 until 10:00 in the morning, affecting almost all the buildings in the city. Its effects on the Church of Santiago were devastating. A large portion of its tower collapsed, also affecting the façade, the roof, the choir section, and some of its chapels. The people of Montilla turned to the Duke of Medinaceli, patron of the church, for help. Fray Francisco Álvarez and the architect José Vela carried out a survey of the property in 1769 and declared the damage of the tower to be severe, arguing for the need of its demolition, carried out by Vela in 1771.

Six years later, two projects for the construction of the new tower were presented to the Duke, one by Vela himself and the other by Fernando Moradillo, a famous Spanish architect of the time based in Madrid, who carried out important projects in the capital city (Figure 7). Finally, the Duke, in line with the wishes of the Montillans, chose Vela's proposal, which underwent some changes. The Moradillo tower (Figure 8) consisted of three sections. The first one with rustic pilasters preserved the style of the Hernan Ruizes. The second one was simple without any adornments, and the bells covered by a double capital with a weathervane. In the center, there was a staircase with a square floor plan, which was supported by the tower walls and illuminated by windows on its sides [28].

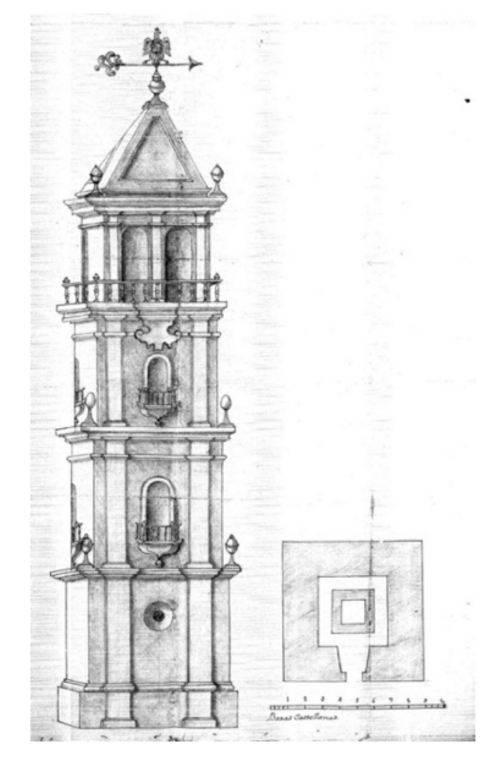

Figure 7. Tower of the Church of Santiago by José Vela. Torre de la iglesia parroquial. Planta y alzado. s.f. (siglo XVIII). (Archivo Ducal de Medinaceli., Mapas y Planos, cajón M. Ref. 1988025218). 


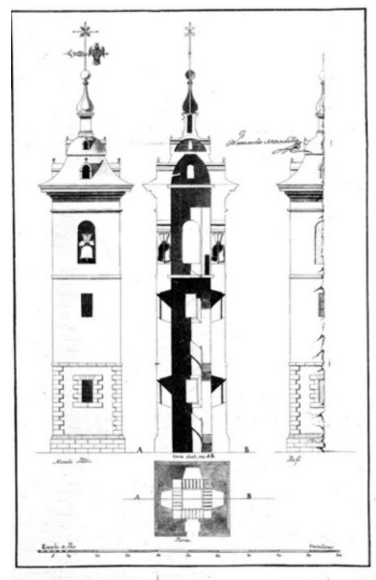

Figure 8. Tower of the Church of Santiago by Fernando Moradillo. Torre de la iglesia parroquial mayor del Señor Santiago. Fernando Moradillo, arquitecto (1777). (Fuente: A.D.M., Mapas y Planos, cajón M. Ref. 1988025219).

In 1989, the architects Juan Carlos Cobos Morillo and Felipe de la Fuente Darder presented a project to rehabilitate the church to the Andalusian Department of Culture [29]. With regards to the tower, they emphasize the structural damage to the three lower bodies, the bell tower, and its roof. Due to the lack of maintenance and the quality of the materials used for the masonry, part of the floor and a bell were in dire condition. The vaults and steps of the ascending staircase also suffered significant damage, with the stair nosing completely ruined, a partial detachment of the paint and mortar, missing pieces and breakage of some windows sills, detachment of the flooring, and heavily deteriorated plaster. The architects also drew attention to the poor design of the last section of the staircase, which made it difficult to evacuate rainwater. The top of the bell tower's cornice, ceramic brick pieces with mortar, was also in a state of deterioration, drowning in the vegetation that grew at the edges of the roof and at the intersection with the wall, which was also causing detachment of brick, the façade, and the breakage of the enamel of the ceramic pieces.

Faced with this situation, the architects proposed an intervention with three focuses: Restoration, restitution, and reconstruction. In the project, in accordance with the time, the principles of eco-sustainable rehabilitation were not yet considered. They began by conducting research of the original construction materials for their replacement and they centered the project around four improvements:

1. Restoration of the windows, with sealing and replacement of defective or worn parts.

2. Cleaning and waterproofing of the roof and its main channels for the evacuation of rainwater.

3. Restoration of the cracks in the dome and the disfigured plaster of the window.

4. General review of plaster.

\subsection{Intervention Proposal Method Applied to the Case Study}

In recent years, various interventions have been carried out in the church, but not in the tower, except for small projects in the bell tower. In a first phase, in 2012, part of the roof and the central nave were reformed, changing the lighting. In 2019, the second phase was concluded with work done on sections including the chapels of the Nacimiento and the Baptistery, the left side of the church, the area of archpriesthood and the primitive sacristy, and the top of the right side.

Although the general state of conservation of the tower after the rehabilitation carried out at the end of the 20th century is acceptable, we understand that it is necessary to carry out interventions that favor its conservation. For this reason, it is necessary to identify the risks that can affect, in the medium and long term, the conservation of the property, defining their impact on the deterioration process and identifying the most vulnerable parts and the degree of protection [30,31]. The windows that line the 
stairwell are open, as well as the ascent to the bell tower, giving way to two main problems: The entry of birds, which deposit highly corrosive organic waste there and nest along the interior of the tower, and the rainwater tower. This can lead to negative effects on the materials and conservation of the tower in the medium to long term. For this reason, we understand that three main interventions can be carried out:

1. Cleaning the roof.

2. Review of the wire mesh window coverings.

3. Cleaning of the inside of the tower.

\subsection{Execution of an Eco-Sustainable Rehabilitation within the Case Study}

As we have just stated, the proposal for an eco-sustainable rehabilitation on the tower of the Church of Santiago Apóstol must focus on three aspects, which we will explain in detail below, while paying special attention to the eco-sustainability of the materials used.

Figures 9-11 show images of the current state of the tower, where the damage caused by the birds that nest inside it and other factors are observed, which help to understand the need for this intervention.

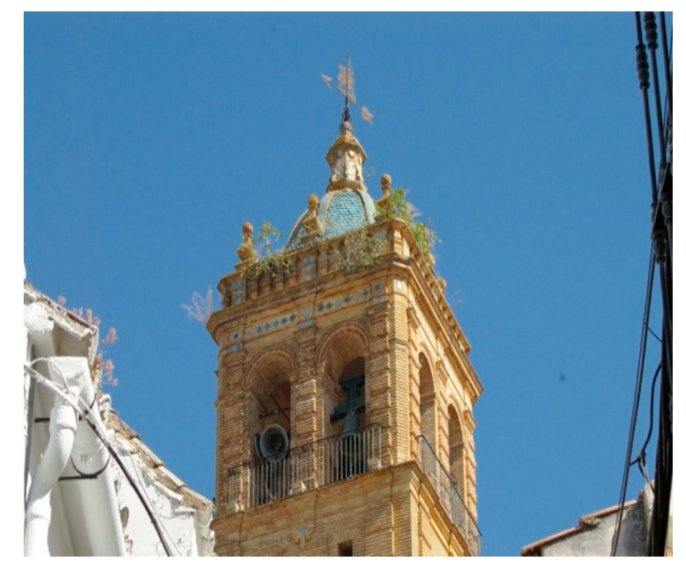

Figure 9. Detail of the current state of the dome.

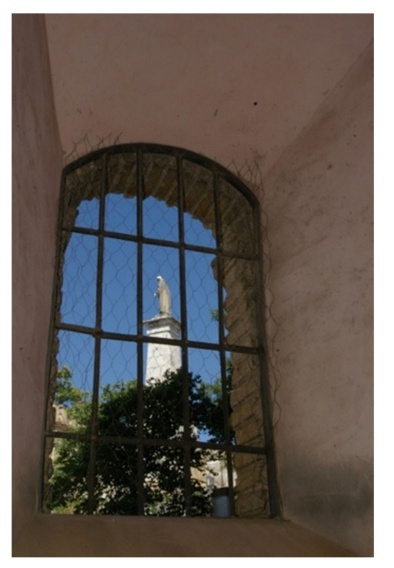

Figure 10. Detail of the current enclosure of one of the windows. 


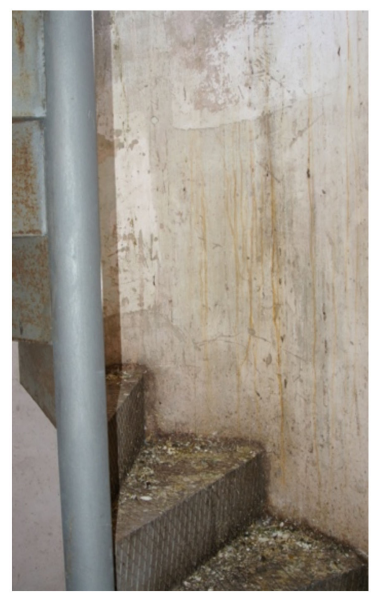

Figure 11. Stairs access to the bell tower.

As it is a specially protected building, the decision-making regarding interventions depends of the Public Administration, so they must be declared to the administration and their established procedure must be followed. As illustrated in Section 2.1, indicators have been determined, as value functions when we extrapolate them to the MIVES method. This way, acceptance rates can be assigned that help when evaluating each indicator in order to evaluate the sustainability of the rehabilitation. These rates will help in the selection of alternatives when one of the aspects gets in the way of an eco-sustainable evaluation of the intervention.

As for the first intervention, cleaning the roof, it is advisable to use soft brushes and small spatulas and to then continue with a deeper cleaning by applying eco-sustainable products to remove plant and organic debris. These products should have a low contamination index and should not negatively affect the glazing of the tiles. A general review of the roof should be carried out to, if needed, replace the defective tiles and check the waterproofing of the roof.

For the second intervention, it is necessary to review the wire mesh covering the windows (Figure 10), as well as the covering made with the same material on the spiral staircase that ascends to the bell tower (Figure 11) in order to avoid the entry of birds by this route. The wire mesh currently in place is in very poor condition. Most of the covering "screens" or nets have either been lost or have large tears that facilitate the entry of birds. For this reason, and to avoid the negative effects of the nesting and the highly corrosive organic residues coming from them on the monument, the revision of the wire mesh screens should be undertaken, and anti-bird netting should be installed.

Finally, with regards to the interior cleaning of the tower, it is necessary to start with an in-depth cleaning of the entire ascending staircase before proceeding to repaint the interior walls.

\subsection{Problems Detected for Eco-Sustainable Rehabilitation in the Case Study}

As we said previously, the rehabilitation of buildings classified with some type of historical-artistic protection such as the one in question is complex, although essential, since it is the responsibility of the towns to safeguard them as part of the cultural heritage of the community [32,33]. Still, we consider the eco-sustainable rehabilitation of protected historical assets as a great challenge.

It must comply not only with the requirements established by the aforementioned legislation, but with various other requirements that are in continuous flux and that have their particularities according to their regulatory framework. A sustainable rehabilitation is one whose interventions on a building are in line with the definition of sustainability understood in a broad sense. In other words, it must consider environmental, economic, and social aspects [34,35].

It should be noted that as it is a specially protected property, interventions on it are limited and those limitations must be respected. The previsions of the Spanish Technical Building Code (CTE) [36] 
and its Basic Documents (DB), which are understood to be all applicable, except that of Energy Saving (HE), which can be exempted, cannot be ignored here.

In the case of the tower studied here, due to the characteristics presented by the study, focus should be placed mainly on the DB of Health (HS), specifically in two of its five requirements: HS1 (Protection against moisture) and HS5 (Water evacuation). Within the concept of sanitation established by the DB-HS, the risk of deterioration of the building due to different factors is included, as we understand happens to this case.

The execution of the three interventions that we consider necessary to undertake in the tower (cleaning the roof, enclosing the windows and the ascent to the bell tower, and cleaning its interior) can pose some problems from an eco-sustainable point of view.

As established by Al Khatib, Soon Poh, and El-Shafie [37], the identification of problems with sustainable materials in interventions in historical settings is an urgent need, since it will help to save on the cost of execution, also reducing the time each intervention takes to complete, contributing to sustainable construction.

Considering their study, we understand that the main obstacles for the eco-sustainable execution of these three interventions in the tower would be:

1. Using eco-sustainable materials and resources.

2. Finding local providers of eco-sustainable resources.

3. Completion time.

4. Management of the waste.

Next we will discuss possible solutions to these obstacles.

The use of eco-sustainable materials such as disinfectants, cleaning products and eco-sustainable paints must be given fundamental importance, as well as the use of brushes, and other tools made with mostly natural elements, with a long durability and high quality. They should also have a low impact on the environment and preserve the historical and aesthetic value of the building.

Regarding the sustainability of the cleaning products used, containers should be made of fully recycled material whenever possible and should be highly effective and efficient. They should also be safe for human health and free of carcinogenic or mutagenic components, heavy metals, ammonia, petroleum, distillates, etc. Its acute oral toxicity must be greater than $5000 \mathrm{mg} / \mathrm{kg}$ and the acute cutaneous toxicity greater than $2000 \mathrm{mg} / \mathrm{kg}$. It is recommended that the $\mathrm{pH}$ be between 2 and 11.5 with a flash point above $93^{\circ} \mathrm{C}$. The cleaning products should also be highly concentrated, in order to reduce water consumption, the actual product to be used per $\mathrm{m}^{2}$ should be calculated, and products should not have been tested on animals. After being diluted aquatically, they should be biodegradable [38].

Traditional paints are synthetic and contain highly polluting elements, such as lead, cadmium, acetone, etc., which release their chemicals over the course of years. We can find four types of ecological paints whose main components are of vegetable or mineral origin. Among them, it is worth highlighting the lime paints traditionally used in Andalusia, which have a high impermeability and fungicidal and antiseptic capacity, preventing the proliferation of fungi, mold, and bacteria. They are very resistant both for indoor and outdoor use. The second kind worth mentioning are clay paints, which have several different shades and are very delicate. They have been used and continue to be used traditionally for plastering walls and their interior layers, such as mortar. Plant-based paints, of mainly organic and vegetable origin, are increasingly used for interiors. The last type, silicate paints, have antibacterial, disinfecting, and fungicidal properties but require specialized professionals for their application and have a higher cost [39].

Regarding the covering of the windows with anti-bird screens, there are several possibilities, depending on the providers. This type of mesh, with its low visual impact, is usually made of two materials: Nylon and polyethylene, both recyclable and highly resistant. The rolls of the highest quality mesh are made by thermoformed knots, with a thickness of between 1.2 and $1.5 \mathrm{~mm}$, diamonds of 4 to $5 \mathrm{~cm}$ and a resistance of between 200 to $250 \mathrm{~kg} / \mathrm{m}^{2}$. This type of mesh lasts between 5 and 15 years. Its 
durability varies depending on whether the mesh is subjected to UV filters, which delay deterioration over time. Another possibility would be the use of metal hunting mesh, which is low cost, has quick installation, and ensures respect for the environment. It is made of galvanized wire with a galvanized finish. Hunting mesh has a low visual impact and high resistance, with the thickness of the wires ranging from $1.9 \mathrm{~mm}$ to $3 \mathrm{~mm}$. The second obstacle centers around having enough environmentally sustainable materials provided. Due to the geographical location of Montilla, in the center of Andalusia, we understand that if it is not possible to find suppliers in Montilla itself that meet these requirements, they can be found in other parts of the region.

The duration of the intervention should also be considered, as it will influence the cost of the project. That is why it is necessary to leave a certain margin when determining the execution times, considering weather problems that prevent work or can cause delays in the delivery of materials.

The last of the problems raised is the management of the waste generated, for which it is necessary to abide by the current legislation, mainly R.D. 105/2008 [40] and Decreto 73/2012 [41] and other European and Spanish legislation applicable.

First of all, it must be taken into consideration that construction and demolition waste (RDC) is "any substance or object generated in construction or demolition and that its owner disposes of or has the intention or obligation to dispose of" [42]. Those residues pose a problem. Their environmental impact can affect soil and water contamination, the non-use of resources, and the deterioration of the landscape, contributing, in turn, to savings in raw materials and the conservation of natural resources. Their treatment is necessary so that they can be correctly disposed of and, where appropriate, recycled and reused, depending on the material in question. As we can see of the general characteristics of the materials recommended for the intervention, they are eco-sustainable materials that do not needing special treatment in terms of general waste management. They can therefore be disposed of at either of the two waste management plants for construction and demolition materials located near Montilla.

As stated above, although the tower is currently in good condition overall, interventions that favor its conservation must be carried out, and we think that, despite the problems of starting work on a protected building, it is possible to do so by applying eco-efficiency criteria. To this end, we have defined the medium- and long-term risks that may affect the conservation of the property in addition to the problems that must be dealt with for an eco-efficient rehabilitation, identifying the most vulnerable parts of this risk and the level of protection [31].

The geographical location of Montilla and the development of the businesses in the area make it possible to acquire materials and contract suppliers and labor locally, causing a positive impact on the local economy.

The roof with four sloping sides facilitates water evacuation, thanks to its four natural drainage points. Its cleaning and the revision of its tiles and waterproofing do not entail great difficulties.

The covering of gaps in the windows will also protect the structure from harsh weather and from the damage caused by entering birds. Given the materials that are proposed for this project, it is understood that the visual impact will be minimal while the changes will be high durable and easy to maintain.

Lastly, the use of eco-sustainable products will be possible in sanitization the of the tower's interior.

\section{Conclusions}

The conservation of specially protected historical buildings, such as the tower of the Church of Santiago Apóstol, is essential for the preservation of the historical, artistic, and cultural values of towns and it facilitates their renovation and renewal over time $[43,44]$. Now, the question we should be asking ourselves is whether it is possible to rehabilitate or carry out interventions on these buildings using eco-efficient criteria.

Eco-sustainability applied to renovations is a recent practice and is usually applied in new buildings or in the rehabilitation of urban periphery and industrial buildings being turned into housing [34,45-48]. Eco-sustainable interventions present important challenges when carried out in 
historical buildings as we must consider the materials used, their impact on the building, the period of execution, cost, economic impact, generation of resources, etc. [37]. Today and the future's society is responsible for the conservation of historical buildings and preservation of the beauty of the heritage left by our ancestors. The approach from an eco-sustainable point of view will generate benefits in the short and long term, also redounding in the surrounding economy [32].

The current health and economic crises make it necessary to find ways to reactivate the economy and, specifically, the Construction Sector. For decades, the depopulation of the rural environment has continued. This crisis is leading part of the population to reconsider returning to rural environments, which are the keepers of a large part of the historical assets and monuments that must be preserved. The eco-sustainable rehabilitation of these buildings is, without a doubt, a process that helps support a circular economy, the enhancement of the environment, the generation of employment in these places, and in some cases, an increase in income derived from tourism.

To determine if an eco-sustainable rehabilitation or intervention is feasible in a specially protected historic building, we have developed a methodology based on the MIVES model and three approaches to sustainability (environmental, social, and economic). In our methodology, the impact on the environment will be measured through indicators that include: Energy consumed, ratio of recycled and reusable materials, management of the waste generated, and number of local service and resource providers and laborers to generate economic benefits in the area. For this assessment, a quality index had been established that will help to determine the execution of an eco-sustainable intervention.

At the end of the 20th century, the tower underwent an important rehabilitation, so today it is not necessary to carry out a major intervention on its structure, although it does require conservation work to ensure its preservation. We specifically recommend an intervention in three parts: (1) Cleaning the roof, (2) covering the windows and access to the bell tower to prevent the entry of birds, and (3) cleaning the interior of the tower. We have determined that there are four main considerations when evaluating an eco-sustainable intervention (the use of eco-sustainable materials and resources, sourcing of eco-sustainable materials and laborers that come from a geographical area near the monument, reasonable duration of the intervention, and safe and effective management of the generated waste), all of which are achievable in our case study.

For these reasons, we think that eco-efficiency criteria can and should be applied, not only as in this case study, but also to other interventions on specially protected historic buildings in rural areas. It will bring benefits not only to their structure and conservation, but also to the surrounding area.

Author Contributions: Introduction, M.A.C.-S.; materials and methods, M.A.C.-S.; results, M.A.C.-S.; conclusions, M.A.C.-S.; writing-original draft preparation and editing, M.A.C.-S.; writing-review, P.M.-M., I.L.C.-G. and F.M.-T. All authors have read and agreed to the published version of the manuscript.

Funding: This research received no external funding.

Conflicts of Interest: The authors declare no conflict of interest.

\section{References}

1. Decreto 111/2001, de 30 de Abril, por el que se Declara Bien de Interés Cultural, Con la Categoría de Monumento, la Iglesia de Santiago, en Montilla (Córdoba). Available online: https://www.juntadeandalucia. es/boja/2001/81/37 (accessed on 28 July 2020).

2. Ley 16/1985, de 25 de Junio, del Patrimonio Histórico Español. Available online: http://noticias.juridicas. com/base_datos/Admin/116-1985.html (accessed on 28 July 2020).

3. Ley 14/2007, de Patrimonio Histórico de Andalucía. Available online: http://noticias.juridicas.com/base_ datos/CCAA/an-114-2007.html (accessed on 28 July 2020).

4. Barbero-Barrera, M.M.; Fernández-Rodríguez, M.A.; Flores-Medina, N.; Pinilla-Melo, J. La materialidad de la arquitectura. In $V$ Encuentro sobre Experiencias Innovadoras en la Docencia; Universidad Complutense de Madrid: Madrid, Spain, 2015; Available online: https://www.edificacion.upm.es/innovacion/2015/18.La\% 20Materialidad_BARBERO_FERNANDEZ_FLORES_PINILLA.pdf (accessed on 28 July 2020). 
5. García-Alvarado, R. Los límites de la materialidad. Tres cualidades arquitectónicas para el próximo siglo. In Arquitectura del Sur; Universidad del Bío-Bío: Santiago, Chile, 1998; Volume 14, p. 27. Available online: https://dialnet.unirioja.es/servlet/articulo?codigo=5231434 (accessed on 28 July 2020).

6. Convención Marco de las Naciones Unidas sobre el Cambio Climático (CMNUCC). Available online: https://www.miteco.gob.es/es/cambio-climatico/temas/el-proceso-internacional-de-lucha-contrael-cambio-climatico/naciones-unidas/CMNUCC.aspx (accessed on 28 July 2020).

7. Protocolo de Kioto. Available online: http://unfccc.int/resource/docs/convkp/kpspan.pdf (accessed on 28 July 2020).

8. Directiva 2010/31/EU del Parlamento Europeo y del Consejo, de 19 de Mayo de 2010, Relativa a la Eficiencia Energética de los Edificios. Available online: https://eur-lex.europa.eu/legal-content/ES/TXT/?uri=celex\% 3A32010L0031 (accessed on 28 July 2020).

9. Bell, S.; Morse, S. Sustainability Indicators Past and Present: What next? Sustainability 2018, 10, 1688. [CrossRef]

10. Viñolas, B.; Cortés, F.; Marques, A.; Josa, A.; Aguado, A. MIVES: Modelo Integrado de Valor para Evaluaciones de Sostenibilidad. In II Congrés Internacional de Mesura i Modelizació de la Sostenibilitat; Centro Internacional de Métodos Numéricos en Ingeniería (CIMNE): Barcelona, Spain, 2009; Available online: https://upcommons. upc.edu/handle/2117/9704?locale-attribute=es (accessed on 28 July 2020).

11. Rüdisser, J.; Leitinger, G.; Schirpke, U. Application of the Ecosystem Service Concept in Social-Ecological Systems-from Theory to Practice. Sustainability 2020, 17, 2960.

12. Wüest, T.; Grobe, L.O.; Luible, A. An innovative Gaçade Element with Controlled Solar-Thermal Collector and Storage. Sustainability 2020, 12, 5281.

13. Quintanilla Raso, M.C. Nobleza y Señoríos en el Reino de Córdoba: La casa de Aguilar (s. XIV-XV), 1st ed.; Monte Piedad y Caja de Ahorros de Córdoba: Córdoba, Spain, 1979; Available online: https://dialnet.unirioja.es/ servlet/libro?codigo $=609190$ (accessed on 28 July 2020).

14. Ramírez de Arellano, R. Inventario-Catálogo Histórico Artístico de Córdoba, 1st ed.; Monte Piedad y Caja de Ahorros de Córdoba: Córdoba, Spain, 1982; p. 431.

15. Lorenzo Muñoz, F.B. Historia de la M. N.L. Ciudad de Montilla, Montilla, Spain, Unpublished work. 1779.

16. Jurado y Aguilar, A. Historia de Montilla, Montilla, Spain, Unpublished work. 1777.

17. Jurado y Aguilar, L. Historia de Montilla, Montilla, Spain, Unpublished work. 1763.

18. Garramiola Prieto, E. Las torres de Santiago (I). Munda-Montulia, Excmo Ayuntamiento de Montilla: Montilla, Spain, Unpublished work. 1979.

19. Nieto Cumplido, M. Aproximación histórica a la historia de Montilla en los siglos XIC y XV. In Montilla, Aportaciones Para su Historia (I Ciclo de Conferencias Sobre la Historia de Montilla); Delegación de Cultura del Excmo. Ayuntamiento de Montilla: Montilla, Spain, 1982; p. 299.

20. García Ortega, A.J. De Mezquitas a Iglesias. Formalización y Trazado en los Procesos de Reconversión de Toledo y Córdoba. EGA Expr. Gráfica Arquit. 2015, 26, 202-211. Available online: https://polipapers.upv.es/ index.php/EGA/article/view/4053 (accessed on 28 July 2020).

21. Suárez Medina, R. El Sonido del Espacio Eclesial en Córdoba. El Proyecto Arquitectónico Como Procedimiento Acústico. Ph.D. Thesis, Universidad de Sevilla, Sevilla, Spain, 2002; pp. 24-31. Available online: https: //idus.us.es/handle/11441/15659 (accessed on 28 July 2020).

22. Delgado López, D. Historia de Montilla. Breve Resumen General de España, Tomo I, Montilla, Spain, Unpublished work. 1895.

23. Morte Molina, J. Montilla: Apuntes Históricos de Esta Ciudad; Imprenta, Papelería y Encuadernación de M. de Sola Torices: Montilla, Spain, 1888; Available online: http://www.bibliotecavirtualdeandalucia.es/catalogo/es/ consulta/registro.cmd?id=1001022 (accessed on 28 July 2020).

24. Baena Sánchez, A. Estudio Histórico-Técnico y Reconstrucción Virtual del Alhorí de los Duques de Medinaceli de Montilla a Través de la Obra del Arquitecto Juan Antonio Camacho de Saavedra. Ph.D. Thesis, Universidad de Córdoba, Córdoba, Spain, 2018. Available online: https://helvia.uco.es/xmlui/handle/10396/16876 (accessed on 28 July 2020).

25. Martín González, J.J. Historia del Arte. Tomo II; Editorial Gredos: Madrid, Spain, 1978; pp. 38-56.

26. Archivo Histórico de Protocolos Notariales de Montilla (A.H.P.N.M.), Escribanos siglo XVI, Legajo 143. Fundación Biblioteca Manuel Ruiz Luque: Montilla (Córdoba), Spain, Unpublished work. 1577. 
27. Navascués Palacio, P. El Libro de la Arquitectura de Hernán Ruiz, el Joven. Estudio y edición crítica, 1st ed.; Escuela Técnica Superior de Arquitectura de Madrid: Madrid, Spain, 1979; p. 16.

28. Sánchez González, A. El arte en la representación del espacio. Mapas y planos de la colección Medinaceli, 1st ed.; Servicio de Publicaciones de la Universidad de Huelva: Huelva, Spain, 2017; pp. 340-341.

29. Archivo Central de la Consejería de Cultura y Patrimonio Histórico de Andalucía (A.C.C.C.P.H.A.) A9.004.14. Consejería de Cultura y Patrimonio Histórico: Sevilla, Spain, 1577; Unpublished work.

30. Suárez, M.; Gómez Baggethun, E.; Benayas, J.; Tilbury, D. Towards an Urban Resilience Index: A Case Study in 50 Spanish Cities. Sustainability 2016, 8, 774.

31. Herráez, J.A.; Pastor, M.J.; Durán, D. Guía para la Elaboración e Implantación de Planes de Conservación Preventiva; Ministerio de Cultura y Deporte: Madrid, Spain, 2019. Available online: https://es.calameo.com/read/ 00007533531922e9ec8e8 (accessed on 28 July 2020).

32. Go-Eum, K.; Jeon-Ran, L. The impact of Historic Building Preservation in Urban Economics: Focusing on Accommodation Prices in Jeonju Hanok Village, South Korea. Sustainability 2020, 12, 5005.

33. Quintana López, T. Urbanismo Sostenible. Rehabilitación, Regeneración y Renovación Urbanas, 1st ed.; Tirant-LoBlanch: Valencia, Spain, 2016; pp. 373-381.

34. Ruiz Palomeque, G. Sustainable renovation management of Large Urban Ensembles by local public administration. Inf. Constr. 2015, 67. [CrossRef]

35. Mercader Moyano, P.; Roldán Porras, J. Evaluating Environmental Impact in Foundations and Structures through Disaggregated Models: Towards the Decarbonisation of the Construction Sector. Sustainability 2020, 12, 5150. [CrossRef]

36. Código Técnico de Edificación Español. Available online: https://www.codigotecnico.org (accessed on 28 July 2020).

37. Al Khatib, B.; Soon Poh, Y.; El-Shafie, A. Materials Challenges in Reconstruction of Historical Projects: A Case Study of the Old Riwaq Project. Sustainability 2019, 11, 4533. [CrossRef]

38. Logic Clean. ¿Cómo es y Cómo se Hace una Limpieza Sostenible? Available online: https://www.logicclean. es/una-limpieza-ecologica-sostenible/ (accessed on 18 July 2020).

39. Arquitectura sostenible. Pinturas ecológicas, 100\% Sostenibles. Available online: https://arquitecturasostenible.es/pinturas-ecologicas-100-sostenibles/ (accessed on 10 July 2020).

40. Real Decreto 105/2008, de 1 de Febrero, por el que se Regula la Producción y Gestión de Residuos de Construcción y Demolición. Available online: http://www.juntadeandalucia.es/medioambiente/portal_web/ web/temas_ambientales/residuos_2/marco_normativo/boe_rcd.pdf (accessed on 28 July 2020).

41. Decreto 73/2012, de 22 de Marzo, por el que se Aprueba el Reglamento de Residuos de Andalucía. Available online: https://www.juntadeandalucia.es/boja/2012/81/4 (accessed on 28 July 2020).

42. Agencia de Obra Pública de la Junta de Andalucía; Consejería de Fomento y Vivienda de la Junta de Andalucía. Gestión y Tratamiento de Residuos de Construcción y Demolición (RCD). Guía de buenas prácticas; Agencia de Obra Pública de la Junta de Andalucía: Córdoba, Spain; Consejería de Fomento y Vivienda de la Junta de Andalucía: Córdoba, Spain, 2015. Available online: http: //www.juntadeandalucia.es/medioambiente/portal_web/servicios_generales/doc_tecnicos/2015/gestion_ tratamiento_residuos_construc_demolic/gestion_tratamiento_residuos_RCD_buenas_practicas.pdf (accessed on 28 July 2020).

43. Sanz Cabrera, J. Restauración de Sta. María la Mayor (SMLM). Baena. Córdoba. Spain. La austeridad y eficiencia en la recuperación de los espacios perdidos. In Libro de Actas del 3er Congreso Internacional de Construcción Sostenible y Soluciones Ecoeficientes; University of Seville: Sevilla, Spain, 2017; Available online: https://idus.us.es/bitstream/handle/11441/59609/Sanz\%20cabrera\%2C\%20jerónimo\%20\%28espa\% 29.pdf? sequence $=2 \&$ is Allowed $=y$ (accessed on 28 July 2020).

44. Corgnati, S.; Filipi, M.; Perino, M. A new approach for the IEQ assessment, research in building physics and building engineering. In Proceeding of the 3rd International Conference on Research in Building Physics IBPC 2006; Taylor \& Francis Group: Montreal, QC, Canada, 2006; Available online: https://www.researchgate.net/ publication/279878849_A_new_approach_for_the_IEQ_Indoor_Environment_Quality_assessment (accessed on 28 July 2020).

45. Blandón, B.; Palmero, L.; di Ruocco, G. The Revaluation of Uninhabited Popular Patrimony under Environmenthal and Sustainability Parameters. Sustainability 2020, 12, 5629. 
46. Diulio, M.P.; Mercader-Moyano, P.; Gómez, A.F. The influence of the envelope in the preventive consevation of books and paper records. Case study: Libraries and archives in La Plata. Elsevier Energy Build. 2019, 183, 727-738. [CrossRef]

47. Candelas-Gutiérrez, A. The Power of Geometrix Relationships in Mudéjar Timber Roof Frames. Nexus Netw. J. 2017, 19, 521-545. [CrossRef]

48. Candelas-Gutiérrez, A.; Borrallo-Jiménez, M. Methology of Restoration of Historical Timber Roof Frames. Application to Traditional Spanish Structural Carpenty. Int. J. Archit. Herit. 2020, 14, 51-74. [CrossRef]

(C) 2020 by the authors. Licensee MDPI, Basel, Switzerland. This article is an open access article distributed under the terms and conditions of the Creative Commons Attribution (CC BY) license (http://creativecommons.org/licenses/by/4.0/). 